\title{
WINE TOURISM AS A VECTOR \\ OF LOCAL AND REGIONAL DEVELOPMENT. \\ CASE STUDY PRAHOVA COUNTY
}

\author{
Adrian Nedelcu, Lecturer, $\mathrm{PhD}^{1}$ \\ Donatella Privitera, Full Time Professor, $\mathrm{PhD}^{2}$ \\ Antonietta Ivona, Associate Professor, $\mathrm{PhD}^{3}$ \\ Alexandru Ganusceac, Travel Agent ${ }^{4}$
}

DOI: https://doi.org/10.31410/tmt.2018.341

\begin{abstract}
Wine and gastronomic tourism is now emerging as one of the most promising segments of the tourism sector. The purpose of this paper is to analyse the Romanian wine heritage, with an impressive historical past, to highlight the considerable potential regarding the development of wine tourism in Romania, the factors that attract and motivate this alternative form of tourism, respectively the efficiency of a network of thematic routes in Dealu Mare vineyard. The study performs a radiography of wine tourism in Dealu Mare region, of the ways in which thematic routes, such as the Wine Road, 14 years after launch, can contribute to the socio-economic development of the Sub-Carpathian region of Prahova, through moderate investments and rapid results. The goals of local development are to encourage an attractive territory and a well-defined identity, with a competitive and efficient agriculture and rural economy with respect for the environment.
\end{abstract}

Keywords: Dealu Mare vineyard, sustainable viticulture, wine tourism, Urlați, Wine Road

\section{INTRODUCTION}

Dourism is a sector that attracted 1,326 million international tourists in 2017 and earned USD 1,340 billion [1]. Romania preferentially polarized a total of 12,222,889 foreign tourists in 2016 and attracted revenues in amount of USD 2,097,000,000 [2]. As seen from these figures, tourism is an important source of revenues for many countries of the world, including Romania. The development of alternative tourism types (such as the wine or gastronomic tourism) would provide an important advantage to tourism destinations, tourism companies in an environment with a high competition. For a growing number of tourists from different countries, tasting beverages and local dishes where they are traveling represents a great part of their most enjoyable experiences.

Wine tourism is one of the tourism forms that has quickly integrated and adapted to the requirements of the world tourist market. The need to know and analyse this tourism form has arisen as a result of the tourism demand change in favour of practicing tourism in the middle of nature and of discovering local traditions, along with wine tasting and knowledge of the technologies for preparing it.

\footnotetext{
1 Petroleum-Gas University of Ploiesti, Faculty of Economic Sciences, Ploiesti, No. 39, Bucharest Avenue, Prahova County, 100680, Romania

2 University of Catania, Department Scienze della Formazione, Catania, No. 4 Via Biblioteca, Italy

3 University of Bari Aldo Moro, Piazza Umberto I, No.1, 70121 Bari BA, Italy

$4 \quad$ BIBI Touring Travel Agency Touroperator Ploiesti, Romania
} 
The dynamism of this tourism form is also supported by the wider spread both in the Old World (Germany, France, Spain, Italy, Portugal, Greece, Serbia, and Romania) and especially in the New World: USA, Argentina, Uruguay, Chile, South Africa, Australia or New Zealand [3].

As a form of travel that has as main theme viticulture and wine production, one can say that wine tourism has emerged as a result of winegrowers' efforts to promote their products and bring consumers into direct contact with the environment and production methods.

The purpose of this paper is to analyse the Romanian wine heritage, to highlight the considerable potential regarding the development of wine tourism in Romania, the factors that attract and motivate this alternative tourism form, respectively the efficiency of a network of thematic routes in Dealu Mare vineyard (Wine Road, Cellar Road, followed by the Vineyard Road in Vrancea County). The study performs a radiography of wine tourism in Dealu Mare region, of the ways in which thematic routes, such as the Wine Road, 14 years after launch, can contribute to the socio-economic development of the Sub-Carpathian region of Prahova, through moderate investments and rapid results.

\section{WINE TOURISM AND ITS DEVELOPMENT}

The beginning of the nineteenth century marks the beginning of wine tourism when visiting vineyards becomes a component part of travel destinations, while, a few decades later, at the middle of the century, wine begins to be a major motivating factor for organized touristic packages. Since 1920, the wine routes have been a tourist activity that slowly but surely crystallizes in Germany in the Rhine Valley, France (especially in Alsace, Burgundy or Champagne) or in Italy (Tuscany). For this reason, in Europe, wine tourism has often been associated with the official wine routes and roads [4].

Traveling to wine-producing regions with vineyards, wine cellars and wineries is not just about visiting them and tasting locally produced wines, either protected designation of origin (PDO) or geographical indication (GI) wines. These trips also take place in order to visit natural sites with valuable landscape or cultural value, to contact wine growers and their wine traditions, to taste local products, to know the local gastronomy or the traditions of the visited areas. Some studies indicate that wine, this divine beverage married with traditional local culinary products, is associated with relaxation, socialization and hospitality [5].

Hall and Macionis (1998) define wine tourism as "a visit to vineyards, wineries, wine festivals and wine shows for which grape wine tasting and/or experiencing the attributes of a grape wine region are the prime motivating factors for visitors" [3]. Other authors analyse wine tourism from three perspectives: the strategy of attracting visitors, the consumption, and lastly the opportunity for wine cellars to educate their clientele and to sell the wine directly from the wine grower [6]. In the "Western Australia Wine Tourism Strategy" (launched in 2000), wine tourism is defined as a "...travel for the purpose of experiencing wineries and wine regions and their links to lifestyle. Wine tourism encompasses both service provision and destination marketing". According to other authors, wine tourism is considered as an alternative tourism form promoted in rural areas that fosters valuable initiatives, such as environmental protection measures, the creation of a network of wine routes, tourist cellars or the development of wine-producing centers [7]. The main motivations of wine tourism are: visiting vineyards by experts in the field of viticulture, for scientific purposes; visiting wine-producing regions by wine buyers for busi- 
ness development (business tourism); visiting vineyards in order to understand the wine production process and tasting it on-the-spot, an activity funded by the winegrowers that perceive it as a promotional activity to encourage sales and to retain potential customers for a long time; knowing wine routes - the road network with a well-defined and attractive theme, generous geographic dimension and a remarkable cultural legacy imposed by the ancient traditions of viticulture and wine production. An example of good practice can be provided by France, Italy, Spain, Germany, the USA or Australia, a country where wine tourism has developed steadily over the past two decades, which is confirmed by the average rate of increase in the number of cellars with a touristic purpose or the increasing number of visitors [8].

A notable success example is Italy, according to Coldiretti (the main European organization of farmers with a million and a half members), food-and-wine tourism earns 5 billion euros in Italy [9].

Other examples may also be Greece, Serbia, Bulgaria and Romania, the last three countries being linked through a "touristic axis" of great importance - the "Cultural Route of the Roman Emperors", with several extensions to areas with an urban cultural, rural traditional or wine-gastronomic heritage of great value [10], [11], [12].

Food is an essential part of the tourist experience, long neglected by scientific studies on tourism. The typicality of food products emerges from link between product and territory of origin because some territories have knowledge consolidated over the years, as well as human and material resources so that food products would not be standardized. But a food product and its production area do not necessarily make themselves a set of attractions sufficient to attract tourists. First, local resources must be analysed critically and then organized thematically and systemically, even including the cultural and natural resources of the considered area. All this requires an appropriate and effective communication of public and private actors who can convey the value of the overall offer of a particular territory as European cases of success demonstrate: La Rioja in Spain, the Rhône-Alpes in France, Langhe, Chianti and Acqualagna in Italy and many others. All cases where operators have skillfully combined the culinary resource with the characteristics of the land and turn them into unique cultural experiences, and able to engage economic virtuous circles [13].

In cultural tourism experience, food-and-wine specifically motivation can be the root element or a factor as important as others (e.g. the productive vocation of the destination; target and economic context). All the territories don't offer food-and-wine tourism and, similar, one can't experience it everywhere [14].

It can, therefore, be said that the symbiosis between business and territory shows full evidence in the case of the wine sector, in which the agricultural nature of the product ensures that its production is strongly characterized by the peculiarities of the territory in which the company is immersed. The product - wine, in particular, is inseparably linked to its terroir, as it derives its specificity and recognition on the market, in terms of tradition and excellence.

\subsection{The Old World}

The place where viticulture has evolved since 7000 BC is Europe, the cradle of vine growing, which is rightly called the Old World, precisely to describe the general differences in the cultivation of grapes and wine production between the ancient regions of the world, where the tradi- 
tions and the role of the terroir stand out, and the New World, where the science and the role of the wine-maker are more often emphasized.

The globalization of wine products and the emergence of new generations of wine-makers have diminished the distinction between the two terms lately. Nowadays, wine-makers in a region are able to produce wines that can present the features of the other region (for example, an "Old World Style" wine can be produced in a New World wine region such as California or New Zealand and vice versa). France, Italy and Spain are the countries with the largest and most important wine-producing regions, but also the beneficiaries of everything that is traditional in the production of wine since ancient times (Figure 1 and Figure 2) [15]. The top five countries cultivating vines in Europe (Spain, France, Italy, Portugal and Romania) have a wine-growing area of $39,165.5 \mathrm{~km}^{2}$ and concentrate a share of $37.85 \%$ of the total area cultivated worldwide [16].

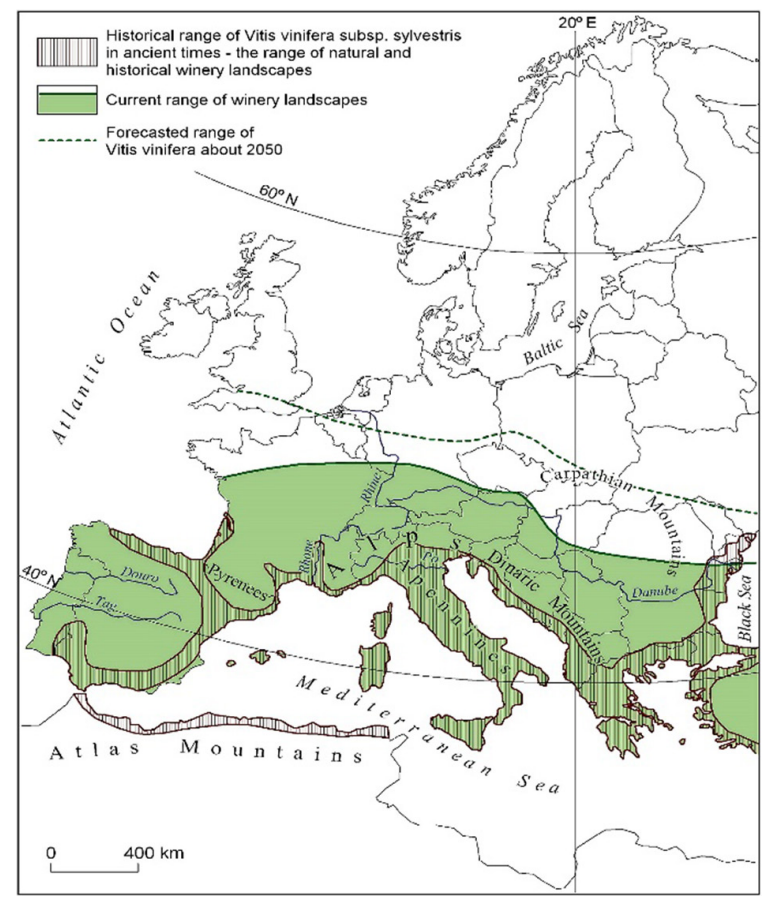

Figure 1. Evolution of wine-growing landscapes in Europe

Source: Myga-Piątek, U., Rahmonov, O. 2018

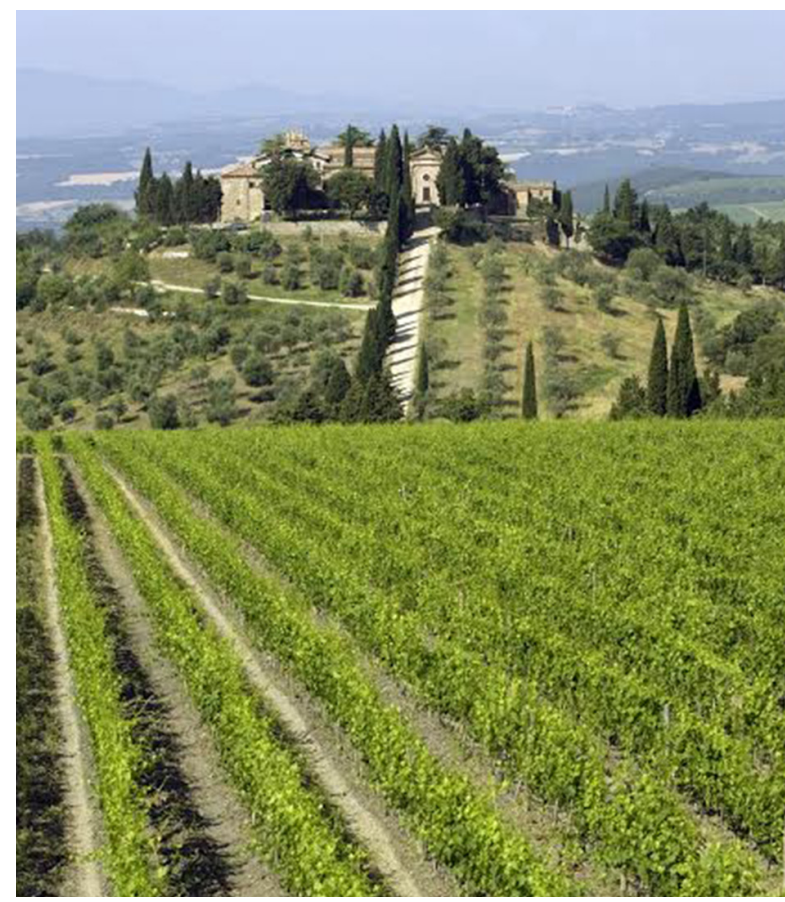

Figure 2.

Vineyard landscape in Tuscany, Italy Source: www.visittuscany.com

Italy holds the European leadership of products recognized across the Community with 262 denominations of origin, 4,813 traditional regional food products, 332 wines with a Registered Designation of Origin (RDO), 73 with a Registered and Certified Designation of Origin (RCDO) and 118 with a Regional Geographical Registration (RGI).

According to a study by the European Commission, RDO and RGI products generate an economic value of 16 billion Euros; including RDO and RGI wines, the value rises to 54 billion [17]. The combination of rural tourism, food and local knowledge is achieved through wine tasting tours, city of taste, farmer markets, festivals and fairs all over Italian territory [11]. A significant example is that of the fairs, they are 42,000 (one fair every five municipalities) with a sales volume of 560 billion Euros. Also, wine routes are an important economic initiative. In Italy there are currently over 150 wine routes with their own website, involving about 1450 municipalities with a turnover of around 2,5 million Euros. 


\subsection{The New World}

Represented by wine-producing areas located in the southern hemisphere and North America, founded by explorers and missionaries from the $14^{\text {th }}$ century, the New World boasts extensive vineyards in countries such as Argentina, Chile, Uruguay, New Zealand, Australia, California and South Africa [18]. In the top 10 world's largest vine growers, with a total area of 69,237.4 $\mathrm{km}^{2}(66.92 \%$ of the total), alongside the Old World renowned countries, there are also three New World countries (the USA, Argentina and Chile), which account for $11.73 \%$ of the area cultivated worldwide (Table 1). Worldwide, there are five New World countries (the USA, Argentina, Chile, Australia and South Africa) in the top ten wine producing countries. This is explained by the warmer and more balanced climate, but dimmed by the western winds or the mountain breezes or by the more productive plantations per hectare. Remarkable are China's efforts to increase the areas cultivating vines and the domestic wine consumption (currently ranking $2^{\text {nd }}$ as cultivated area and $9^{\text {th }}$ in terms of wine production - Table 1 and Table 2).

\begin{tabular}{|c|c|c|c|c|c|c|}
\hline Rank & Country & $\mathbf{2 0 1 1}$ & $\mathbf{2 0 1 2}$ & $\mathbf{2 0 1 3}$ & $\mathbf{2 0 1 4}$ & $\begin{array}{c}\text { \% of world } \\
\text { production }\end{array}$ \\
\hline $\mathbf{1}$ & Spain & $13,708.8$ & $13,420.8$ & $13,461.1$ & $13,478.4$ & $13 \%$ \\
\hline $\mathbf{2}$ & China & $8,496.0$ & $9,475.2$ & $10,817.3$ & $11,370.2$ & $11 \%$ \\
\hline $\mathbf{3}$ & France & $10,874.9$ & $10,828.8$ & $10,823.0$ & $10,805.8$ & $10.4 \%$ \\
\hline $\mathbf{4}$ & Italy & $10,212.5$ & $9,930.2$ & $9,993.6$ & $9,820.8$ & $9.5 \%$ \\
\hline $\mathbf{5}$ & Turkey & $7,228.8$ & $7,073.3$ & $7,171.2$ & $7,142.4$ & $6.9 \%$ \\
\hline $\mathbf{6}$ & USA & $5,621.8$ & $5,863.7$ & $5,996.2$ & $5,961.6$ & $5.8 \%$ \\
\hline $\mathbf{7}$ & Argentina & $3,110.4$ & $3,150.7$ & $3,191.0$ & $3,179.5$ & $3.1 \%$ \\
\hline $\mathbf{8}$ & Chile & $2,931.8$ & $2,931.8$ & $2,960.6$ & $3,001.0$ & $2.9 \%$ \\
\hline $\mathbf{9}$ & Iran & $3,024.0$ & $3,058.6$ & $2,954.9$ & $2,920.3$ & $2.8 \%$ \\
\hline $\mathbf{1 0}$ & Portugal & $2,557.4$ & $2,557.4$ & $2,557.4$ & $2,557.4$ & $2.5 \%$ \\
\hline $\mathbf{1 1}$ & Romania & $2,488.3$ & $2,511.4$ & $2,517.1$ & $2,494.1$ & $2.4 \%$ \\
\hline & World total & $\mathbf{1 0 0 , 4 9 4 . 7}$ & $\mathbf{1 0 1 , 1 1 1 . 0}$ & $\mathbf{1 0 3 , 1 1 5 . 5}$ & $\mathbf{1 0 3 , 4 4 9 . 6}$ & $\mathbf{1 0 0 \%}$ \\
\hline
\end{tabular}

Table 1. Main wine-producing countries in the world (in $\mathrm{km}^{2}$ ) Source: International Organization of Vine and Wine (IOVW) [18]

\begin{tabular}{|c|c|c|c|c|c|c|}
\hline Rank & Country & $\mathbf{2 0 1 1}$ & $\mathbf{2 0 1 3}$ & $\mathbf{2 0 1 4}$ & $\mathbf{2 0 1 5}$ & $\begin{array}{c}\text { \% of world } \\
\text { production }\end{array}$ \\
\hline $\mathbf{2}$ World total & $\mathbf{2 6 , 5 4 3 , 8 0 0}$ & $\mathbf{2 7 , 8 8 5 , 4 0 0}$ & $\mathbf{2 8 , 2 3 0 , 4 0 0}$ & $\mathbf{2 8 , 3 9 5 , 9 0 0}$ & $\mathbf{1 0 0 \%}$ \\
\hline $\mathbf{1}$ & Italy & $4,673,000$ & $5,402,900$ & $4,473,900$ & $4,950,000$ & $17.43 \%$ \\
\hline $\mathbf{2}$ & France & $4,432,200$ & $4,107,500$ & $4,670,100$ & $4,750,000$ & $16.73 \%$ \\
\hline $\mathbf{3}$ & Spain & $3,535,300$ & $3,123,300$ & $3,820,400$ & $3,720,000$ & $13.10 \%$ \\
\hline $\mathbf{4}$ & USA & $2,692,400$ & $3,114,600$ & $3,021,400$ & $2,975,000$ & $10.48 \%$ \\
\hline $\mathbf{5}$ & Argentina & $1,547,000$ & $1,498,400$ & $1,519,700$ & $1,340,000$ & $4.72 \%$ \\
\hline $\mathbf{6}$ & Chile & 966,500 & $1,282,000$ & $1,050,000$ & $1,290,000$ & $4.57 \%$ \\
\hline $\mathbf{7}$ & Australia & $1,109,000$ & $1,250,000$ & $1,200,000$ & $1,190,000$ & $4.19 \%$ \\
\hline $\mathbf{8}$ & South Africa & $1,046,300$ & $1,097,200$ & $1,131,600$ & $1,120,000$ & $3.94 \%$ \\
\hline $\mathbf{9}$ & China & $1,156,900$ & $1,170,000$ & $1,117,800$ & $1,100,000$ & $3.87 \%$ \\
\hline $\mathbf{1 0}$ & Germany & 697,300 & 910,200 & 849,300 & 890,000 & $3.13 \%$ \\
\hline $\mathbf{1 1}$ & Portugal & 562,200 & 623,100 & 620,600 & 670,000 & $2.36 \%$ \\
\hline $\mathbf{1 2}$ & Russia & 698,000 & 529,000 & 488,000 & 460,000 & $1.62 \%$ \\
\hline $\mathbf{1 3}$ & Romania & 405,800 & 331,000 & 511,300 & 350,000 & $1.23 \%$ \\
\hline
\end{tabular}

Table 2. Main wine-growing countries in the world (liters 000)

Source: International Organization of Vine and Wine (IOVW) [18] 
Just as wine-makers in the New World have learned from Italy or France about wine-making, the Old World also has something to learn from its New World competitors in this respect [19].

The improvement of wine production techniques, the use of Old World techniques to obtain more complex wines (fermentation in oak barrels, use of unselected yeast, mixing of sediments, etc.) make the border between the New and Old World wines ever more subtle.

Success examples are Australia and New Zealand. They have developed new wine and food products and styles of cuisine, and used these to develop wine tourism as an important link between networks of local producers and global markets [20]. Especially in the case of wine and food tourism in Australia, government has created specific organizations and the provision of funding for education, research, cooperative strategies, improving existing networks between the private and public sector [20].

\section{WINE TOURISM POTENTIAL IN ROMANIA}

Romania, as a wine-growing and wine-producing country, occupies the $5^{\text {th }}$ place in terms of the wine-growing area in the European Union and the $6^{\text {th }}$ place in terms of the production of grapes and wine. The surface cultivated with vines occupies about $1.4 \%$ of the entire agricultural area of the country. Alongside Romania, in the Balkan Peninsula, in 2014, there were also important areas of viticulture in Greece $\left(1566.7 \mathrm{~km}^{2}\right)$, Serbia $\left(714.2 \mathrm{~km}^{2}\right)$, Croatia $\left(374.4 \mathrm{~km}^{2}\right)$, Macedonia $\left(299.5 \mathrm{~km}^{2}\right)$, Slovenia $\left(230 \mathrm{~km}^{2}\right)$, Montenegro $\left(121 \mathrm{~km}^{2}\right)$, Albania $\left(121 \mathrm{~km}^{2}\right)$, Bosnia-Herzegovina $\left(74.9 \mathrm{~km}^{2}\right)[21]$ - Figure 3 and Figure 4.

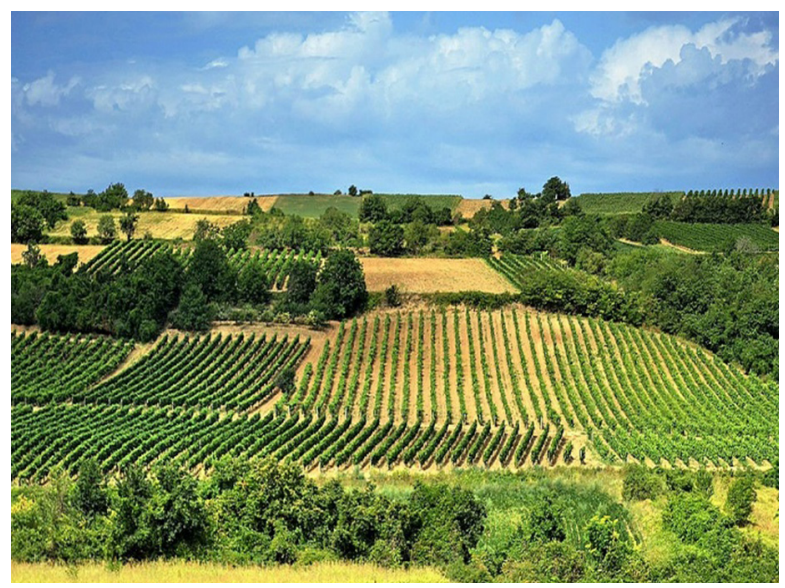

Figure 3. Vine culture in Fruška Gora, Serbia Source: www.winesofbalkans.com

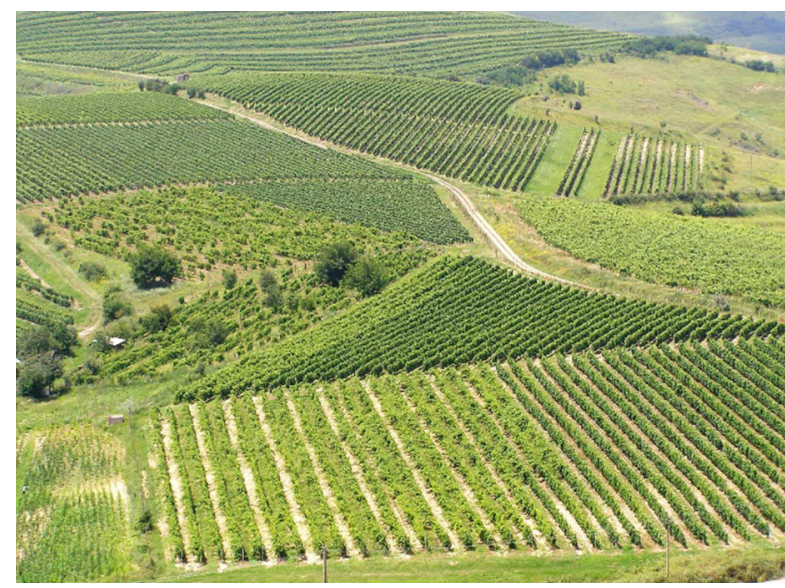

Figure 4. Landscape from Dealu Mare vineyard, Romania Source: Nedelcu Adrian, 2014.

The "engine" of wine tourism development in Romania is offered mainly by the wine heritage, appreciated and acknowledged by the numerous medals won at international contests in Paris, Brussels, Berlin, Daejeon (South Korea), Québec or Buenos Aires.

In the space between the Carpathians, the Danube and the Black Sea, viticulture has been practiced since the earliest times. Testimonies are the material traces discovered in Dobrogea region, but also the written evidence left by the Romanian poet Ovidiu, which attests the age of practicing this culture, two and a half millennia ago [22]. 
Since 1990, viticulture and the wine production industry have experienced extensive and radical transformations in Romania: vineyards have been the property of winegrowers; hybrid varieties have been replaced by noble varieties for the production of quality wines accepted in the EU; the establishment of new vineyards with recommended noble varieties, which best value the environmental conditions and highlight the qualitative and productive potential in the cultural areas delimited to the level of the territorial administrative locality.

In the first international viticulture statistics, Romania had a wine-growing area of $973.8 \mathrm{~km}^{2}$ and a wine production of $946,347 \mathrm{hl}$ in 1876 , while, in 1982, the area grew to $2998.7 \mathrm{~km}^{2}$. After Romania's adherence to the European Union (2007), the wine-growing area gradually decreased to $2494.1 \mathrm{~km}^{2}$ (2014), but grew in quality [2].

At the same time, it has experienced structural and qualitative changes in order to develop a performing and sustainable viticulture by: introducing the native varieties into the crop $(50 \%$ of the total wine-growing area); increasing the share of wines with protected designations of origin (PDO), increasing the share of red and aromatic wines in the total wine production; promoting wine consumption; strengthening the producers' association for the creation of viable vineyards eligible for community financial support [22]. 52.5\% of the Romanian wine-growing area is cultivated with noble varieties $\left(1309.4 \mathrm{~km}^{2}\right)$ and $47.5 \%$ with hybrid varieties $\left(1184.7 \mathrm{~km}^{2}\right)$.

The group of valuable native grape varieties includes the following: white wines (Feteasca regală, Feteasca albă, Grasa de Cotnari); red wines (Băbeasca neagră, Feteasca neagră); aromatic wines (Tămâioasa românească and Busuioaca de Bohotin) [23].

In the group of foreign origin varieties, the following stand out by the higher frequency in culture: white wines (Italian Riesling, Aligoté, Sauvignon and Chardonnay); red wines (Merlot, Cabernet Sauvignon, Pinot noir, Burgundy and Shiraz); aromatic wines (Muscat Ottonel) [23].

\subsection{Wine Tourism in Prahova County}

Prahova County, member of AREV (Assembly of European Wine regions), together with the other three counties from Romania (Alba, Arad and Vrancea), is said to hold an important potential to become a renowned region in Eastern Europe in the wine tourism sector, if we consider the fact that Dealu Mare region (Figure 1), located on the same parallel with Tuscany and Bordeaux, disposes of all the natural factors to come close to the good practices of this tourism form on a medium term. In the last ten years, it has become well-known nationally and internationally in the wine sector. The wine tourism features in Romania became appreciated only after 1999, when the Halewood Romania Group launched this form of tourism through modern wine cellars with special areas for the reception of tourists, wine tasting, restoration, with accommodation, a wine museum or winery outlet (the Rhein Wine Cellars and guest house in Azuga, in the north of Prahova County, the only sparkling wine factory in the country that has been operating continuously since 1892), visited annually by about 20,000 tourists, of which about $40 \%$ are foreign tourists arriving in groups from Europe, Asia or North America [25].

In 2004, the first thematic route project (the Wine Road in Dealu Mare region, Prahova County) was launched in Romania, aiming at revitalizing the wine-growing area. The wine routes have multiplied as soon as the wine producers have facilitated the access of tourists to their properties through mutual cooperation with hotel owners, restaurant owners and local authorities: Cellar Road in Dealu Mare vineyard, Buzău County (Năieni-Săhăteni-Pietroasele-Zoreşti-Verneşti), 
Vrancea Vineyards Road (Tâmboieşti-Coteşti-Odobeşti-Panciu), Wine Road in Arad vineyard (Păuliş-Ghioroc-Covasânţ-Şiria), Vâlcea Wine Road, the wine road network in the vineyards of Alba County (Târnave, Sebeş-Apold, Alba Iulia, Aiud), Satu Mare Wine Road, Dobrogea Wine and Traditions Road [26]. Various tourist reception structures have gradually appeared in the proximity of these wine routes, carrying out different functions: accommodation, public catering, therapy or leisure, which potentiate the wine-growing landscapes of Moldavia, Banat, Transylvania, Dobrogea or those of Muntenia and Oltenia.

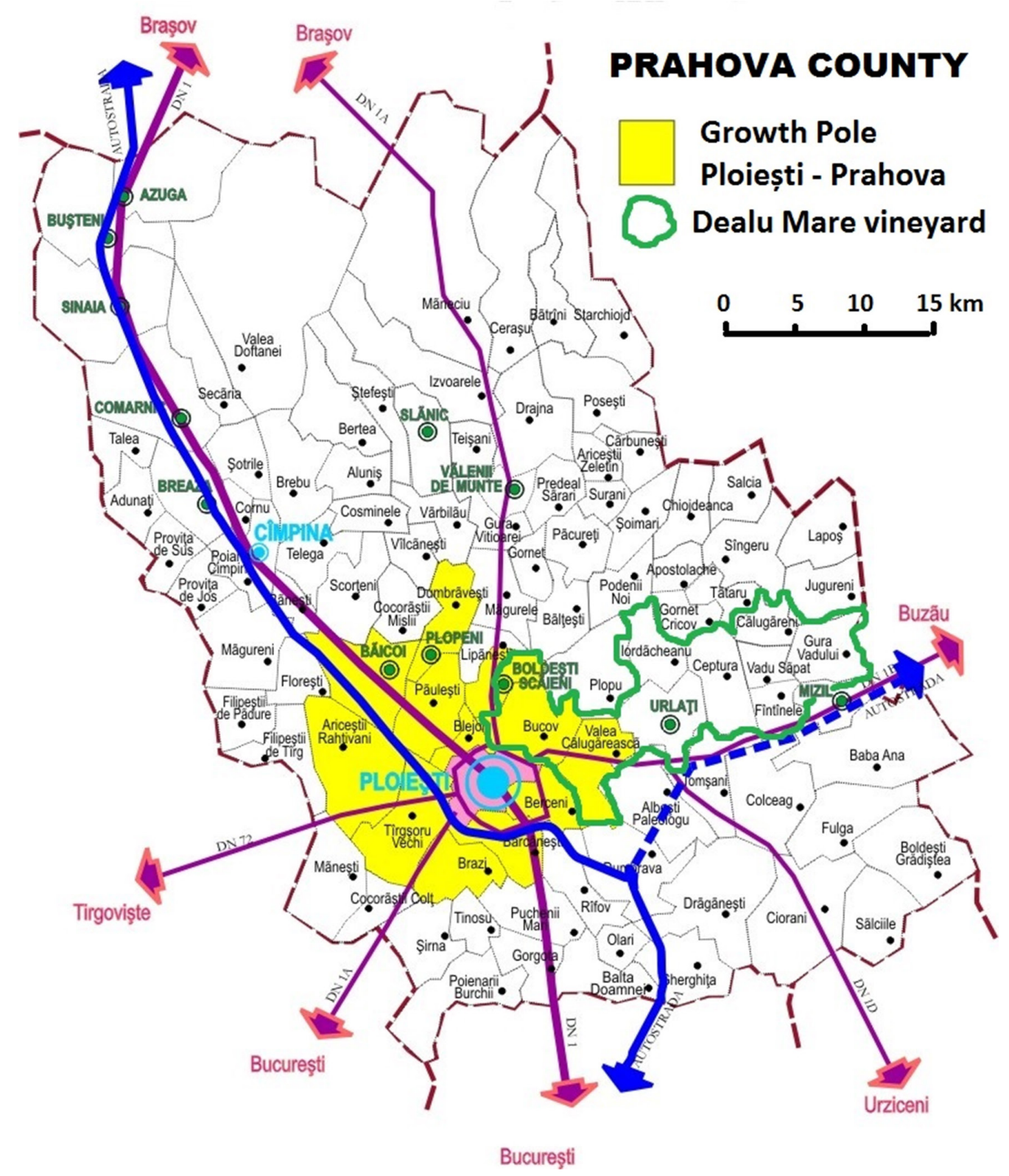

Figure 5. Prahova County-the position of the Dealu Mare region Source: Nedelcu, A. 2013 [24]

Dealu Mare vineyard in Prahova County, acknowledged as the "Red Wine Land", has an important potential to become a renowned region in Central and Eastern Europe in the field of wine tourism, taking into account that the region, relying on the same parallel as Tuscany and Bordeaux wine regions, has all the natural factors to achieve the good practices of this form of tourism [26], [27]. 

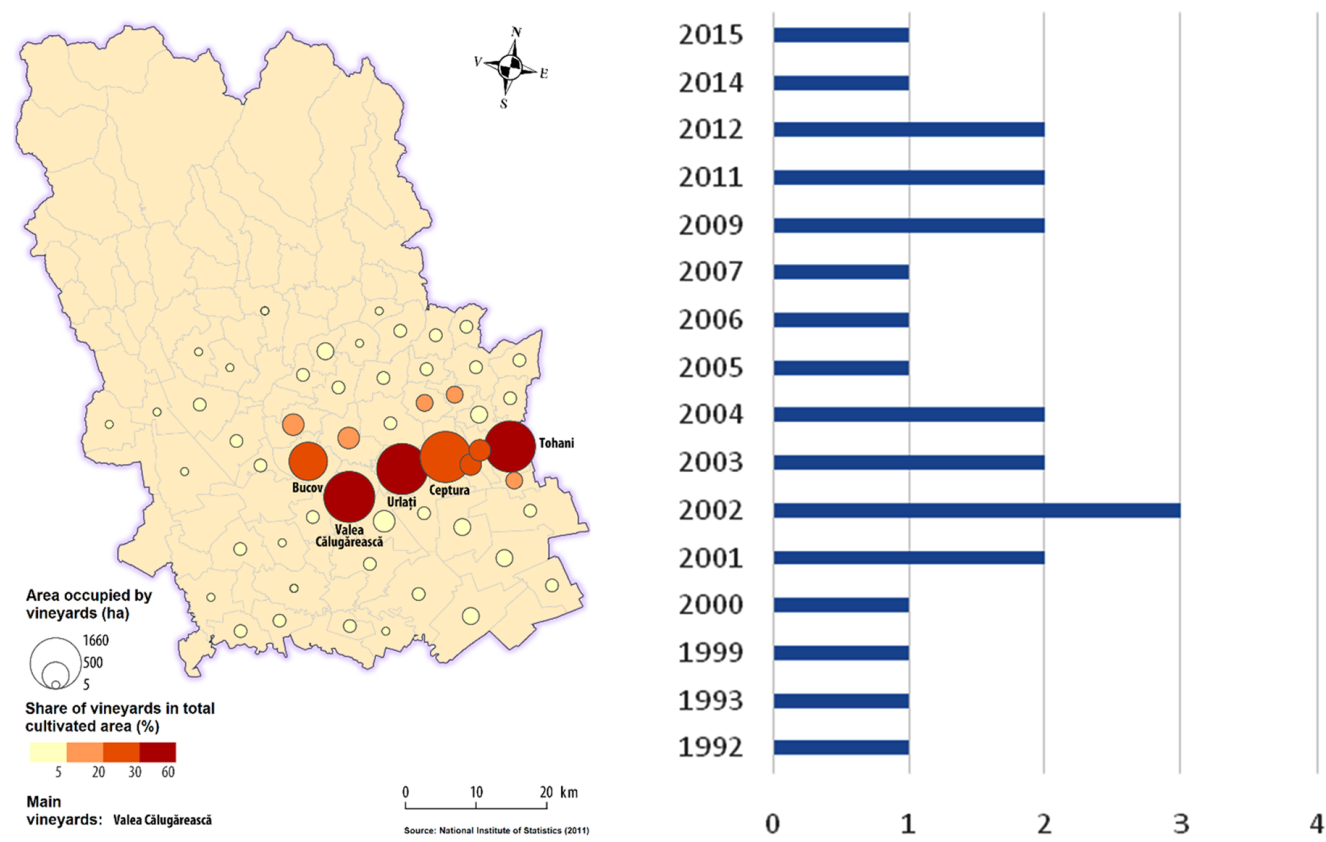

Figure 6. Wine centers in Prahova County and the number of open wine cellars per year, between 1992-2015

Source: Mihai Bogdan et al. [27] and Ganusceac, A., 2018.

The wine-growing region of Dealu Mare benefits from several strong points, such as:

- the balanced spatial distribution of the wine-growing fields, based on the existing wine-growing centers (Valea Călugărească, Urlați, Ceptura, Tohani), functionally covering an extended influential space;

- the strategic geographical position close to Bucharest $(60-90 \mathrm{~km})$, as well as the easy access to the region from Otopeni and Băneasa airports;

- the proximity of large and very large urban centers (Bucharest, Brașov, Ploiești, Buzău, Galați or Brăila), which can issue considerable tourist flows, attracted by the features of wine tourism;

- the location in the vicinity of European and national roads [28], ensuring the connection to other main tourist poles (Transylvania, the Danube Delta, Moldavia), namely A3 Motorway, E60 European Route - a road considered to record the highest road traffic in Romania, especially on the sector Bucharest-Ploiești-Brașov (where the annual road traffic ranges between 6,000,000 and 10,000,000 vehicle transitions), E577 and E85 European Routes, represents an ,engine” for the regional economic development (Figure 1);

- the renowned wine-growing and wine production traditions and the attractive touristic resource variety;

- the existence of a young clientele (25-40 years) with a purchase power above average;

- the climate conditions fostering touristic activities;

- the increase of the interest in natural products and the return to nature;

- the increasing popularity of movements such as the slow-food movement;

- the considerable potential to attract investors in wine-growing centers;

- the important research, development and innovation capacity (Research and Development Institute for Viticulture and Oenology, Petroleum-Gas University of Ploiești);

- the existence of local cooperation partnerships (Local Action Groups) in the viticulture and wine production sector between the rural localities from Prahova and Buzău Counties, elements that can aim to create a destination of excellence for Romanian wine tourism. 
The Wine Road in Dealu Mare includes 27 wine cellars (of which 20 are wine cellars open to tourists) plus 3 wine-producing complexes (Halewood România, Valea Călugărească and Tohani) and a research unit in viticulture and wine production nationwide at Valea Călugărească (Figure 6). The localities crossed by the wine route are: Boldeşti Scăieni (1 cellar), Bucov (1 cellar), Valea Călugărească (2 cellars), Vărbila, Jercălăi, Urlaţi (5 cellars), Ceptura (5 cellars), Vadu Săpat (1 cellar), Gura Vadului (4 cellars), Tohani (1 cellar).

The main tourist attractions of the theme routes in Dealu Mare region are:

- visits to wine cellars and wine tasting: Seciu Wine Cellar, Lady Ralu's Manor in Bucov, Bunescu-Kelaru Wine Cellar in Valea Călugărească, Urlățeanu Manor, Basilescu Wine Cellar, Stenota Wine Cellar, Bolgiu Wine Cellars and Dealu Mare Domains in Urlați, SERVE, Rotenberg and Davino in Ceptura, Vitis Metamorfosis Wine Cellar from Vadu Săpat, Budureasca, Licorna Winehouse, Tohani Domains and Oenoterra Wine Cellar from Gura Vadului;

- adventures on the cycling route from Dealu Mare vineyard (140 km long between the Ghighiu and Ciolanu monasteries, which can be crossed in 5 days);

- visits to religious buildings: monasteries (Ghighiu, Zamfira, Jercălăi, Vărbila) and churches (Mizil wooden church which is $52 \mathrm{~m}$ tall);

- admiring the extraordinary panoramas on the top of some hills in Seciu, Stânca Tohani (site of community importance within the Natura 2000 ecological network);

- visits to museums or museum collections such as: 1777 Wine Cellar in Valea Călugărească, Bellu Manor in Urlaţi, the "Tohani on the wine road" permanent exhibition.

Even if large funds have been invested in the cellars, some of which comply with European standards (Budureasca Wine Cellar, Licorna Winehouse, Basilescu, Stenota) or in tourist reception structures with accommodation, catering or entertainment functions, some having a high degree of comfort, ranking 4 or 5 stars (Conacul dintre Vii boutique hotel from Urlați or Sky Blue Hotel\&Spa Păulești), which face a reduced tourist flow (increasing compared to 2010), a small sales volume, and the profits are small despite the facilities designed for the visit.

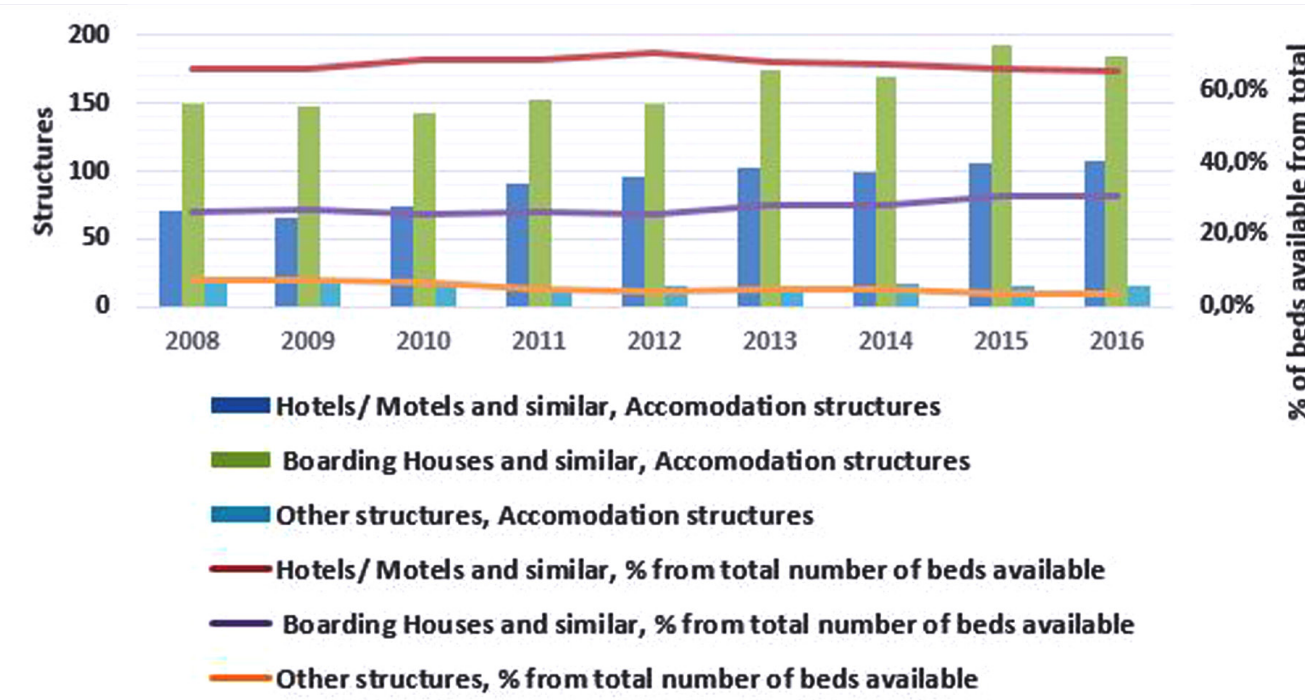

Figure 7. Number of accommodation structures and percentages of beds available (2008-2016) in Prahova County Source: National Institute of Statistics, 2018 [2] 
The increase in the number of tourist guest houses and hotels in the region in recent years (Figure 7) reveals an increase in the interest for wine tourism, but almost $60 \%$ of the accommodation capacity in Dealu Mare region has a reduced comfort, while tourists aim more at units with a medium (three star), high (four stars) and luxury (five stars) comfort [2].

\subsection{Wineries in Dealu Mare Vineyard}

For the professionals in the field, wine tourism may be defined by three words: recreation, vineyards and wineries, and the vines represent an economic capitalization of the less fertile lands, but also the protection of the environment and its revaluation, without affecting its integrity. 20 wineries operate in Prahova County, the turnover being of approximately USD 71.8 billion. Most of these wineries are small in size. These are family businesses that rarely exceed the average of approximately 25 employees and have a limited production capacity (Table 3 ).

\begin{tabular}{|l|c|c|c|c|}
\hline \multicolumn{1}{|c|}{ Wine cellar } & $\begin{array}{c}\text { Cultivated } \\
\text { surface (ha) }\end{array}$ & $\begin{array}{c}\text { Number of } \\
\text { employees }\end{array}$ & $\begin{array}{c}\text { Bottles/ } \\
\text { year }\end{array}$ & $\begin{array}{c}\text { Turnover } \\
\text { (US \$) }\end{array}$ \\
\hline Domeniile Tohani & 365 & 83 & 3.750 .000 & 8.263 .327 \\
\hline Budureasca Wine Cellar & 275 & 47 & 3.000 .000 & 6.272 .399 \\
\hline Vitis Metamorfosis Wine Cellar & 100 & 20 & 100.000 & 637.473 \\
\hline S.E.R.V.E. Wine Cellar & 54 & 42 & 700.000 & 2.372 .178 \\
\hline Licorna Winehouse Cellar & 35 & 17 & 100.000 & 417.563 \\
\hline Rotenberg Wine Cellar & 23 & 14 & 75.000 & 511.775 \\
\hline
\end{tabular}

Table 3. The cultivated surface, the number of employees, the wine production and the turnover for 2017 of some wine cellars in the Dealu Mare region Source: Ministry of Public Finances, 2018. [28]

Budureasca Wine Cellar, Gura Vadului. Budureasca River valley lies in the area of the first Sub-Carpathian hills, $30 \mathrm{~km}$ from Ploiesti. The river terraces comprise 31 archaeological sites, the densest ancient human settlement in Dacia. The archaeological evidence found nearby suggests that this place has a tradition rich in wine production, dating since the Dacians [29].

Viile Budureasca Company was founded in 2001 and currently has one of the most modern constructions for wine production in the region and in the country. The wine cellar was opened in 2013 and has an area of 5,300 square meters with a storage capacity of 2.5 million liters of wine. The wine-producing complex includes three major areas: the production/fermentation zone, the conditioning/storage area and the wine maturing area in oak barrels. The complex also has offices and several tasting spaces, including views of the barrel hall, as well as an outlet for marketing and sale. The company cultivates an area of nearly 300 hectares of vines, of which 250 ha have been replanted, whereas the old varieties are preserved on 30 ha, and 7.5 ha are destined for the production of organic wines [29].

The wines produced in Budureasca are classified as follows: $55 \%$ are red wines (Cabernet Sauvignon, Feteasca neagră, Merlot, Pinot Noir and Shiraz) and 45\% are white wines (Sauvignon Blanc, Feteasca Regală, Tămâioasa Românească, Chardonnay, Feteasca albă, Pinot Gris, Riesling and Muscat Ottonel). The winemaker of the winery is Stephen Donnelly, an international oenologist with more than 30 years of experience, known as the "Flying Winemaker". He began his career in Napa Valley, then he travelled to England, Hungary, South Africa, India and Romania. Since 2007, he has won over 70 gold and silver medals at famous world contests such as Rose du Monde, Mundus Vini, Mondial du Merlot, Decanter, Mondial de Bruxelles, and the 
International Wine Challenge. Budureasca Wine Cellar exports its wines to Japan (Fetească neagră); Belgium (Chardonnay and Fume); China, the Netherlands and the United Kingdom (premium wines) [29].

Rotenberg Wine Cellar, Ceptura. The wine cellar was founded in 2007, when the current owner and wine producer, Mihail Rotenberg, purchased the old wine cellar from Ceptura, which was severely damaged. The wine cellar has been gradually renovated in a "boutique" style and reminds of its old splendor, being visited by more and more tourists each year. Rotenberg Wine Cellar is also one of the main sponsors of "George Enescu" International Music Festival. It has a wine-growing surface of 23 ha on the territory of Ceptura and Fântânele towns, mostly cultivated with Merlot, Cabernet Francs and Cabernet Sauvignon (Table 3). For a high degree of quality, the grape production is limited to 6 tons/ha, and the grape harvest and selection is performed manually only. It is a producer of artisan premium wines, using a gravitational wine production unit, where the wine is exclusively produced according to the traditional method, without any trace of industrialization or robotization [30]. The grapes are separately fermented on planes here, producing the "Single vineyard" wines. The red wine is fermented in semi-opened containers, with a submerged cap. Although it is expensive and non-industrial, this procedure confers wines a special distinction, which cannot be attained in stainless steel tanks. The two overlapped cellars allow the gravitational technological flow where the wine is not mechanically stirred by the pumps. The wine flows from the fermentation containers into the barrels and from the barrels into the bottles under the influence of its own weight, thus avoiding the mechanical filtering. 75,000 bottles of wine are produced each year [30].

The cellar wine brands (Merlot Rapsod, Merlot Arlequin, Merlot Menestrel, Merlot Notorius, Merlot Emeritus, Merlot Classic, Rose Rotenberg) were awarded many medals at various international and national competitions, among which the silver medal awarded for Rotenberg Merlot 2006 at the "Mondial du Merlot" Competition from Switzerland (2010).

SERVE Wine Cellar, Ceptura. Count Guy de Poix, winemaker who managed to make his mark in Corsica (France) for more than 20 years, has chosen Romania in spite of its discouraging appearance in the post-revolution period, having a vision of the qualitative potential of Dealu Mare vineyard. For him, Romania would become the country where he and his wife, Mihaela, would create "S.E.R.V.E." Wine Cellar in 1993, producing exceptional wines from the production of 60 hectares (Cabernet Sauvignon, Feteasca neagră, Pinot noir, Merlot, and some of the white varieties such as Chardonnay and Fetească albă) [31].

The construction of the new wine cellar began in 2000 and the first bottling took place in 2001, the first crop becoming wine in 2002. Built in 2012, the tasting pavilion, with a capacity of 35 people and access to a spacious courtyard, the wine cellar can host special events such as team building tastings or small private events. The company has participated in several international competitions where it has won over 30 medals [31].

Vitis Metamorfosis Wine Cellar, Vadu Săpat. With the consent of the Antinori family (specialized in the vine culture in the Tuscany region for over 600 years), in 2002, in Vadu Săpat, a joint venture emerged between the English Halewood company, the oenologist Fiorenzo Rista and Marchesi Antinori [32].

At present, Vitis Metamorfosis domain in Dealu Mare vineyard has an area of 100 hectares planted with Cabernet Sauvignon, Fetească neagră, Negru de Drăgăşani, Fetească regală, Fe- 
tească albă, Tămâioasă Românească, Muscat Ottonel, Merlot, Syrah, Pinot noir, Sauvignon Blanc or Chardonnay (Table 3).

The cellar of the company was completely renovated and refurbished between 2012 and 2013. It has an area of 13,000 square meters, of which 5,000 square meters are built, with a processing capacity of 1,000 tons and the storage capacity of 11,500 hectoliters. The most important international contests in which the wine cellar took part are the Decanter World Wine Awards, The Global Cabernet Sauvignon Masters and International Wine Contest Bucharest. The wine of the wine cellar was awarded medals at all these contests. The wine cellar organizes vineyard walks and tasting tours for passionate tourists.

Licorna Winehouse Cellar. Licorna Winehouse Complex is located in Gura Vadului, in Dealu Mare vineyard. Founded in 2013, the complex comprises a wine production center with a grape processing capacity of 150 tons/year and a bottling line capacity of 1,000 bottles/hours, a product warehouse with two areas (one for the ageing of wine bottles and another for the storage of the products ready for delivery), as well as a beautiful noble manor built during 1907-1909 by Italian stone masons [33]. The total investment value amounts to more than EUR 3 million and the cellar annually produces approximately 130,000 liters of wine under brands like Serafim, Licorna, Bon Viveur, Anno. Licorna Winehouse owns approximately 35 ha in the region of Dealu Mare, where the following Romanian varieties distinguish: Fetească albă, Fetească regală, Tămâioasă românească and Fetească neagră, but also the most famous international varieties - Chardonnay, Sauvignon blanc, Merlot and Cabernet Sauvignon [33].

The young oenologist of the cellar, Gabriel Lăcureanu, designated oenologist of the year 2016 in Romania, was awarded two gold medals for Bon Viveur 2014 (the symbol of the cellar) at Berliner Wine Trophy (2017) and at Decanter World Wine Awards (2018).

Domeniile Tohani Wine Cellar is located in Dealu Mare vineyard in the eastern extremity of Prahova County, in Tohani village (Gura Vadului Town). The wine-growing estates spread over seven hills, on approximately 365 ha, facing south-east and blessed by a special climate with 14 sunny days more than other wine-growing regions of the country [34].

Thus, the grapes mature earlier and have more time to acquire quality features. The Mediterranean microclimate, which allows figs and almond trees to grow, offers the vine special development conditions, which give the Tohani wines intense colour and flavours, texture and a balance of the senses. Over 300 million bottles are produced each year and the cellar owns highly appreciated wine brands in Europe, Asia or North America and that are awarded medals at many national or international competitions. Apogeum, Valahorum, Principele Radu, Moșia de la Tohani, Princiar, Domeniile Tohani distinguish among the brands. The last creation of oenologists Albertus van der Merwe and Marin Ion is Flori de Gheață brand, is the first ice wine produced at Dealu Mare vineyard. The only wine collection from the area is preserved here, housing over 100,000 collection wine bottles. The construction of a new factory with state-ofthe-art technology in the 2000s and the re-cultivation of the vines on considerable surfaces have also modernized the wine-growing estates. The quality of the wine produced by Tohani Wine Cellar was acknowledged in 2012 when the company became the purveyor to the Royal House of Romania [34].

All these wineries, regardless of their size, have recorded an increase in their turnover. To survive the competition represented by the large wineries, the smaller ones focus on the diversification of their offer, targeting a new customer segment that can be served right at the winery. 
We can say that these wineries go through a transition or a reconversion in order to serve the tourists, the winemakers also becoming tourist service providers. For some of them, this is an alternative to create a renowned international brand, a long-term strategy that has a lot of benefits especially for wine tourism, although it also bears certain risks.

\section{THE IMPORTANCE OF WINE TOURISM IN THE LOCAL ECONOMIC DEVELOPMENT}

Wine tourism can generate an increase in the profitability of the tourist activity, as well as the assertion of a sense of satisfaction for the quality of the service, which may also be favourable prerequisites for expanding this activity.

More and more wine, cheese and honey festivals, included in the development and marketing plans of most of the destinations and the administrative-territorial units from Prahova County, are events that combine wine and food in a "marriage" relationship. These are traditional products specific to Dealu Mare region, and important elements that serve the competitiveness of the touristic destination.

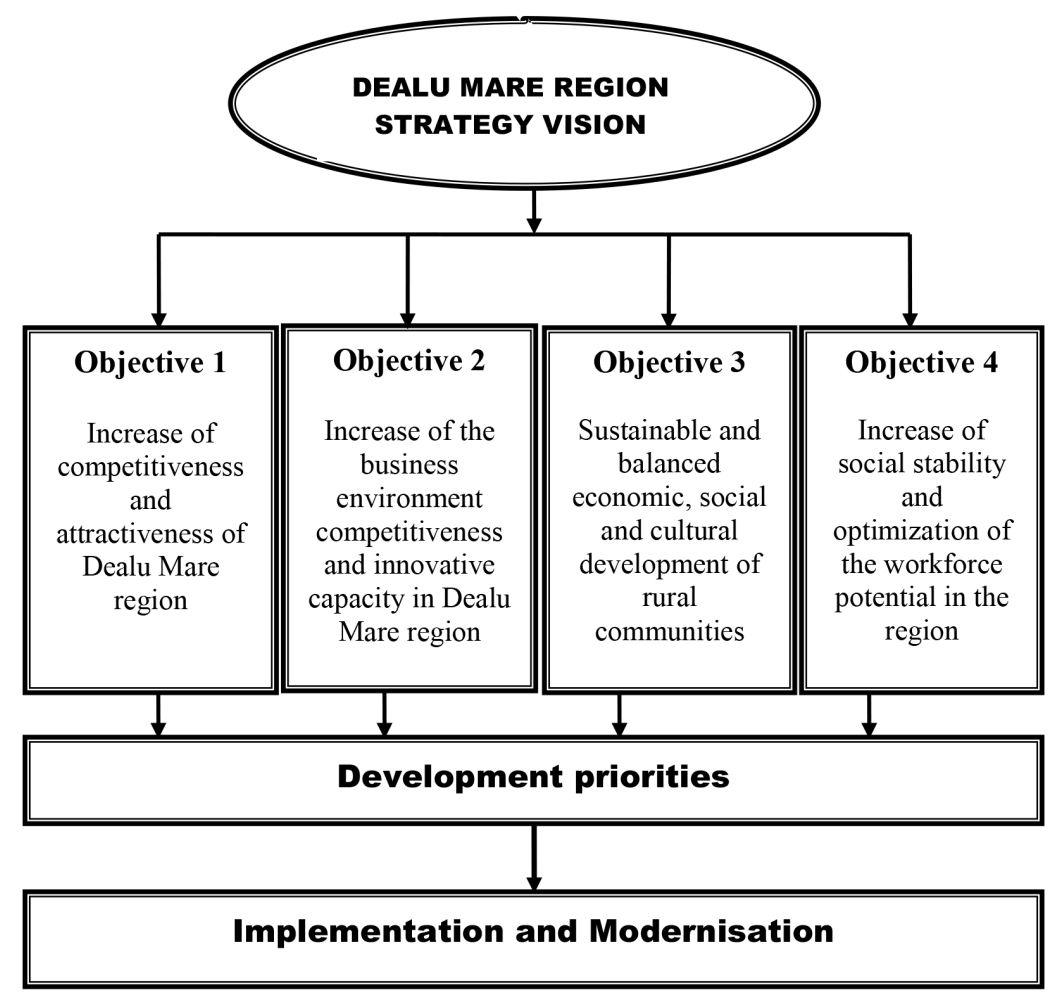

Figure 8. Development strategy vision in Dealu Mare region

Wine tourism is closely related to the hilly rural space specific to Dealu Mare region, therefore it answered the economic difficulties faced in the ' 90 s by the agricultural sector. Together with rural tourism, wine tourism contributes to the growth of local economy, of workforce employment and of the population's incomes, as well as of the town infrastructure (roads, bridges, water supply, electricity and telecommunications). This growth, in turn, may drive the development of other industrial sectors that are closely related to the rural, cultural tourism. It may bring some residential facilities, such as sports and entertainment facilities. It may contribute to the 
development and diversification of the (trading, educational, financial and banking, transport, medical) services, and, last but not least, it may efficiently contribute to the preservation of cultural and environmental resources. The development of thematic routes in the space of Dealu Mare region (Wine Road, Fruit Road, the Route of Rulers, Salt Road), combined with a series of activities, cultural events (festivals dedicated to the wine, the plum brandy, the cheese, the cooking art, etc.) and the open air attractions represent elements that may drive cooperation and partnerships between the local areas and may contribute to the local development [35].

For Prahova County, wine tourism may bring significant benefits to the local communities from the wine-growing area of Dealu Mare vineyard, by improving business competitiveness, by addressing the social needs and by preserving the cultural and natural environment. The wine-growing surface located on the territory of Prahova County represents a true heritage of a great value if we consider that 1 ha of vine equals 8 ha of cereals in terms of economy. In the wine-growing region of Prahova, made of 3 towns (Mizil, Urlați, Boldești-Scăieni) and 8 localities (Gura Vadului, Călugăreni, Vadu Săpat, Fântânele, Ceptura, Iordăcheanu, Valea Călugărească, Bucov), territorial development is targeted through a large-scale strategic vision (including here the Development Pole Ploiești-Prahova), integrating the three dimensions - economic, social, cultural - by acknowledging that this development is supported by people and communities (Figure 8).

\section{CONCLUSIONS}

Through its geographical location, Prahova County plays an important regional and national role in the territorial and economic cohesion and may become an integrated part of the national economic development axis formed of the urban areas of Bucharest, Ploieşti and Braşov. In this context, tourism is the link between the economy, the urban and the rural civilizations, a great potential triggering the development not only of the urban space, but also of the rural one.

The combination of tourism and agriculture is undoubtedly the main activity in Dealu Mare region, but also the viable solution for local and regional sustainable development. The products specific to the rural households (wine products, meat, milk, cheese, honey, fruit and vegetables, etc.) of Prahova can be capitalized through wine or gastronomic tourism, both indirectly and directly.

More and more wine, cheese and honey festivals, included in the development and marketing plans of most of the destinations and the administrative-territorial units from Prahova County, are events that combine wine and food in a "marriage" relationship. These are especially traditional products specific to Dealu Mare region, and important elements that serve the competitiveness of the touristic destination. Tourism can and must be the link between the economy, the urban and the rural civilizations, a huge and challenging potential for rural development in Dealu Mare region.

The two traditional activities (viticulture and wine production) allow a better balance of economic, social and cultural development through the spatial diffusion of the growth impulses generated by the wine-producing centers - the engines of local and regional sustainable development. Wine tourism, a tourism component from Prahova County, is a sub-sector with a high potential for development, thus representing an occupational alternative for the rural workforce, a way of diversifying the economic activities in rural areas and stabilizing the rural population. 
A sustainable development of wine tourism implies three main directions of action: increasing private investment in premium wine cellars, high comfort accommodation and catering; investments in public infrastructure and activities promoting Dealu Mare region brand.

Wine tourism is able to bring significant benefits to the local communities from Dealu Mare region by improving the competitiveness of businesses/companies, by responding to social needs and, above all, by preserving the cultural and natural environment. But it is important to remember that wine regions must compete with other tourist destinations so policy-makers should carefully consider whether initiatives are necessary and should be market driven.

\section{REFERENCES}

[1] UNWTO, Tourism Highlights 2018 Edition.

https://www.e-unwto.org/doi/pdf/10.18111/9789284419876, Accessed October 2018.

[2] Institutul Național de Statistică, Turism, Tempo online

[3] Halle, C.M., Macionis, N. (1998) Wine tourism in Australia and New Zealand. Tourism and Recreation in Rural Areas, Sydney: John Wiley and Sons, pp. 267-298.

[4] Hall, C.M., Sharples, L., Cambourne, B., Macionis, N. (2000) Wine tourism around the world, Oxford: Butterworth-Heinemann.

[5] Dodd, T. H. (1997) Opportunities and pitfalls in a developing wine industry, International Journal of Wine Marketing, Vol. 7 (1), pp. 5-17.

[6] Getz, D., Dowling, R., Carlsen, J., Anderson, D. (1999) Critical success factors for wine tourism, International Journal of Wine Marketing, 11(3), pp. 20-43.

[7] Soare, I., Costachie, S. (2013) Ecoturism și turism rural, Editura Europlus, Galați.

[8] Pratt, M. (2011) Profiling wine tourists, more than just demographics, in AWBR International Conference, Bordeaux Management School, 9-10 June.

[9] Coldiretti (National Confederation of Direct Cultivators)

Website: https://www.coldiretti.it/, Accesed October 2018.

[10] Pivac, T. (2012) Vinski turizam Vojvodine, Monografija, Prirodno-matematički fakultet, Departman za geografiju, turizam i hotelijerstvo, Stojkov, Novi Sad.

[11] Ivona, A. (2015) Economic effects of rural tourism. Farm, food-and-wine and enhancement of cultural routes, in Bambi G. (edited by), The European Pilgrimage Routes For Promoting Sustainable And Quality Tourism In Rural Areas, Firenze, Firenze University Press, pp. 779-791.

[12] Terzić, A., Bjeljac, Ž. (2016) Cultural Routes - Cross-border Tourist Destinations within Southeastern Europe, Forum Geographic, Vol. XV (2) December, pp. 180-188. http://dx. doi.org/10.5775/fg.2067-4635.2015.041.d, Accessed October 2018.

[13] Paolini D. (2002) I luoghi del gusto. Cibo e territorio come risorsa di marketing, Baldini\&Castoldi, Milano.

[14] Croce, E., Perri, G. (2010) Food and Wine Tourism. Integrating Food, Travel and Territo$r y$, Cambridge University Press, Cambridge.

[15] Miętkiewska-Brynda, J., Makowski, J. (2018) Viticultural landscapes in transition: permanence and change, Miscellanea Geographica - Regional Studies on Development, Volume 22 (2), pp. 63-68. https://doi.org/10.2478/mgrsd-2018-0015, Accessed October 2018.

[16] Myga-Piątek, U., Rahmonov, O. (2018) Winery regions as the oldest cultural landscapes: remnants, signs, and metamorphoses, Miscellanea Geographica - Regional Studies on Development, Volume 22 (2), pp. 69-80. doi: https://doi.org/10.2478/mgrsd-2018-0009, Accessed October 2018. 
[17] Istituto Nazionale di Economia Agraria (2014) L'agricoltura in Italia Multifunzionalità, Diversificazione e Servizi, Website: http://antares.crea.gov.it:8080/documents/ 10179/227001pdf, Accessed October 2018.

[18] International Organization of Vine and Wine (IOVW), Website: http://www.oiv.int/, Accessed October 2018.

[19] Antonioli Corigliano, M. (2011) The route to quality: Italian gastronomy networks in operation, in Hjalager A. and Richards G. (Eds), Tourism and Gastronomy, Routledge, NY, pp. 166-185.

[20] Hall, C.M., Mitchell, R. (2011) The changing nature of the relationship between cuisine and tourism in Australia and New Zealand: from fusion cuisine to food networks, in Hjalager A. and Richards G. (Eds), Tourism and Gastronomy, Routledge, NY, pp. 186-206.

[21] Jahić, H. (2016) Wine tourism and wine roads in Herzegovina-Neretva Canton - situation and prospects, Acta geographica Bosniae et Herzegovinae, Vol. 6, pp. 83-99.

[22] Soare, I., Man O., Costachie S., Nedelcu A. (2010) Viticultural potential and wine tourism in Romania, Journal of Tourism, Vol. 10, pp. 68-74.

[23] MADR (Ministerul Agriculturii și Dezvoltării Rurale), http://www.madr.ro/docs/dezvoltare-rurală, Accessed October 2018.

[24] Nedelcu, A. (2013) Growth Pole Ploiești - Prahova - tool for regional development, in Recent Researches in Business Administration, Product Design and Marketing, Chania, Crete Island, Greece, Vol. I, (1), pp. 169-178.

[25] Nedelcu, A. (2015) Tourism Geography, University Publishing House, Bucharest.

[26] Dinu, M., Cohen, N., Dombay, S., Nedelcu, A. (2015) Some models of thematic routes practiced in wine regions, Transylvanian Journal of Tourism and Territorial Development, Vol. 1 (2), pp.1-15.

[27] Mihai, B.A., Nedelcu, A., Buterez, C. (Eds) (2016) Județul Prahova. Spațiu, societate, economie, mediu, Editura Academiei Române, București.

[28] Ministry of Public Finance, http://www.mfinante.gov.ro/agenticod.html?pagina=domenii, Accessed November 2018.

[29] Viile Budureasca SRL. https://budureasca.ro/, Accessed October 2018.

[30] Crama Rotenberg SRL. https://www.rotenberg.ro/, Accessed November 2018.

[31] Societatea Euro Româna de Vinuri de Excepție (SERVE). https://www.serve.ro/despre-noi/crama, Accessed November 2018.

[32] Vitis Metamorfosis SRL. http://www.vitis-metamorfosis.com/, Accessed October 2018.

[33] Crama Licorna Winehouse. http://www.licornawinehouse.ro/ Accessed October 2018.

[34] Domeniile Tohani SA. https://www.tohaniromania.com/, Accessed November 2018.

[35] Briedenhann, J., Wickens, E. (2004) Tourism routes as a tool for the economic development of rural areas-vibrant hope or impossible dream? Tourism Management, Vol. 25 (1), pp.71-79. 